\title{
Specifics of Cyberbullying of Teachers in Czech Schools - A National Research
}

\author{
Kamil KOPECKÝ, René SZOTKOWSKI \\ Palacký University Olomouc, \\ Faculty of Education, Centre for prevention of risky virtual communication \\ Olomouc, Czech Republic \\ e-mail:kamil.kopecky@upol.cz,rene.szotkowski@upol.cz
}

Received: November 2016

\begin{abstract}
This paper focuses on the results of the national research of cyberbullying of Czech teachers, which was realized in year 2016 in the entire Czech Republic. The research focused on the prevalence of cyberbullying of teachers, the impact of cyberbullying on teachers, strategies of coping with cyberbullying and methods of solving the incidents. The research involved a total of 5,136 primary and secondary school teachers from all regions of the Czech Republic. The research has shown that a fifth of respondents $(21.73 \%)$ has experienced a cyber attack on their person, however cyberbullying during the last 12 months lasting over 1 week was confirmed only by $3.52 \%$ of the total number of respondents. Most often the cyberattacks were committed by students $(34.92 \%$ of attacks).
\end{abstract}

Keywords: cyberbullying of teachers, strategies of coping with cyberbullying.

\section{Introduction}

\subsection{Specifics of Cyberbullying of Teachers}

In recent years, there has been an increasing number of cases in which the target of single or repeated cyberattack is a teacher. Cases of aggressive behaviour in children (but also adults - the parents) to teachers are confirmed by research carried out in Europe, USA and other countries.

Among the best known and most widely used definitions of cyberbullying are definitions of the American researchers Hinduja and Patchin who define cyberbullying as a deliberate, repeated and hurtful activity using computer, mobile phone and other elec- 
tronic devices (Hinduja and Patchin, 2009; Patchin and Hinduja, 2006). In the last decade new definition have been proposed, with particular attention to the criterion of repetition. As suggested by Slonje and colleagues, (Slonje, Smith, and Frisén, 2013) - the idea of repetition within cyberbullying is not as straightforward.

Typical forms of cyberbullying, to which students but even teachers can be exposed, include (Kyriacou and Zuin, 2015; Willard, 2007b):

- Flaming: sending angry, rude and vulgar messages about a person to an online group or person via email or other text messages.

- Online harassment: repeatedly sending offensive messages via email or text to the other person.

- Cyber-stalking: harassment that includes online threats of harm.

- Denigration or trolling: sending harmful, untrue or cruel statements about a person to other people or posting such materials online.

- Masquerading: Pretending to be someone else and sending or posting materials about the person that makes the victim look bad.

- Outing: sending or posting material about a person that contains sensitive, private or embarrassing information.

Specific forms of cyberattacks linked to various Internet services, derived from above forms cyberbullying, which may (but need not) be involved in cyberbullying of teachers, include:

- Cyberbaiting (provoking the teacher and recording his/her surprised reaction mostly through mobile phones, and subsequently sharing of these materials).

- Sharing degrading material depicting a teacher (mostly sharing photos and videos that were taken in schools, or outside the school environment) and subsequent comments on these materials.

- Creating fake websites demeaning the teacher.

- Creating fake profiles dishonouring the teacher (e.g. in social networking sites).

- Threats and intimidation of teachers.

- Extortion of the teacher.

- Penetration into an online account of the teacher and subsequent theft of the teacher's identity.

The classification given above was created on the basis of the analysis of more than 500 cases of cyber-attacks against the teachers and was recorded online by the Centre for Prevention of Risky Virtual Communication at the Palacký University in Olomouc from 2010 to 2016. Similar classification is also used by the researchers from European countries and also in the USA (Espelage et al., 2011; GEW, 2008; Kauppi and Pörhölä, 2012b; Lipsett, 2009; Pearson, 2014; Posnick-Goodwin, 2012).

All these forms of cyber-attacks can be implemented not only on a one-time basis, but also repeatedly. Thus, they can become part of both cyberharrasment and real cyberbullying.

We can understand how big is the prevalence of cyberbullying of teachers based on the results of the surveys carried out over the last 10 years. 


\subsection{Prevalence of Cyberbullying of Teachers}

One of the first studies of cyberbullying of teachers was conducted by the Union for Education and Science in Frankfurt in 2007 (GEW, 2008). This nationwide research involved 488 teachers who were divided into two categories according to whether cyberbullying affected them directly or indirectly. The bulk of the sample (65\%) were affected indirectly by cyberbullying - this means that victims of cyberbullying were their friends and colleagues. According to this research $8 \%$ of teachers became the victims of cyberbullying (Hollá, 2012). In most cases the teachers were sent intimidating and threatening messages via mobile phone and Internet services.

The US National School Boards Association survey realized in 2006 confirmed that $26 \%$ of teachers and headmasters in USA became the victim of cyberbullying from their students (Pearson, 2014; Posnick-Goodwin, 2012). More than 40\% of respondents believe that the behaviour of pupils worsened significantly in the last two years.

In 2009 there was carried out a survey by the British Association of Teachers and Lecturers (ATL), spanning more than 1,000 respondents (Association of Teachers and Lecturers, 2009; Garrett, 2014). The study focused particularly on students' behaviour in the classroom. Approximately one quarter of school staff (23.5\%) confirmed that they became victims of physical assault by students. Other forms of attacks on teachers include verbal abuse (insults, slander), intimidation, disrespecting the instructions of the teacher etc. Nearly 40 percent of teachers also said that they became victims of aggressive behaviour of the child's parents, the most common was a reaction to the punishment of their child by the teacher.

Important information about bullying teachers is also provided by a study from researchers in Finland (Kauppi and Pörhölä, 2012a), which took place in years 20082009 , and spanned over 215 Finnish teachers. Researchers interviewed them to establish whether, and how often teachers become victims of bullying from students. $25.6 \%$ said that sometimes, $3.3 \%$, almost every week, and $3.7 \%$ almost daily.

The teachers stated that in their belief the main reasons why the bullying took place, was especially student behaviour problems, family problems (e.g. bad parenting), problems associated with puberty and the fact that teachers are a certain authority to which pupils respond in different ways. Authors of the study believe that these attitudes of teachers are their "psychological defence" (Kauppi and Pörhölä, 2012a; Kyriacou and Zuin, 2015) - for teachers it is easier to look for causes of the bullying perpetrated on them in a response of pupils to their authority or to search for causes in the students' personal problems related to e.g. puberty, rather than realizing that there are a number of reasons related to e.g. the personal characteristics of teachers and their attitude to the class (and its management). The study also points out that if teachers are bullied, they most often look for help from their colleagues (50\%), school management (21.4\%) or their partner (11.4\%). Kauppi and Pörhölä also attempted to find out what forms of bullying teachers face (Kauppi and Pörhölä, 2012b). From the group of respondents the researchers separated the 70 teachers who were victims of bullying, and analysed what forms of bullying they were exposed to. 
The most common forms of attacks were obscene or inappropriate comments, refusal to obey, repeated lying, mocking, insulting, offensive gestures etc. $14.7 \%$ of bullied teachers also confirmed that they became the target of harassment via e-mail, phone calls or SMS messages. Cyberbullying (e.g. sharing dehumanizing photos, writing of inappropriate comments) was confirmed by $7.6 \%$ of teachers who were victims of bullying.

Other interesting findings concerning cyberbullying of teachers were provided by the research conducted by the British Teacher Support Network and The Association of Teachers and lecturers in 2009 (Lipsett, 2009). The research involved 539 teachers from Great Britain. According to the results of this research $15 \%$ of teachers became the victim of cyberbullying. The most common forms of attacks were verbal aggression (vulgar messages), degrading and humiliating photographs and hateful comments in social networking sites. $45 \%$ of respondents also confirmed they witnessed cyber attacks against their colleagues (Lipsett, 2009).

Results of a research from the University of Plymouth in 2011 (Posnick-Goodwin, 2012) show that $35 \%$ of teachers and their colleagues have experienced cyberbullying in cyberspace in the form of online harassment, especially in the environment of Facebook or Twitter. Most often the cyberbullying had the form of 'reviews on teachers' published on the server RateMyTeacher, hate groups aimed at teachers on Facebook and inappropriate videos on YouTube. The attackers were $72 \%$ students, $26 \%$ of the pupils' parents.

In 2011 the Task Force on Violence Directed Against Teachers (Espelage et al., 2013; McMahon et al., 2014; Reddy et al., 2013) conducted a research in USA, which focused on whether and how much the K-12 school teachers are exposed to violence. The research conducted by the American Psychological Association ${ }^{1}$ (APA) involved nearly 3,000 teachers $(n=2998)$ of the 48 US states. $80 \%$ of them confirmed that in years 2010 and 2011 they became a victim of violence perpetrated by students. In attacks on teachers were involved also parents of pupils $-45 \%$ were intimidated, while in $44.4 \%$ the perpetrator was a parent (McMahon et al., 2014). 4\% of teachers $(\mathrm{n}=124)$ also became victims of an attack in Internet environment.

According to the British research carried out by NASUWT (a union bringing together teachers from England, Northern Ireland, Scotland and Wales), which involved more than 7,500 teachers, $21 \%$ of British teachers became a victim of cyberbullying (NASUWT, 2014). The most common forms of cyber attacks on teachers were uploading and sharing of humiliating and offensive messages/comments about teachers, harassment and other forms of verbal aggression in social media and online forums. More than a quarter of teachers $(26 \%)$ confirmed that they had seen videos and photos made by their pupils without their consent and published on the Internet.

According to the research, $64 \%$ of teachers were molested by pupils, $27 \%$ by the pupils' parents and $9 \%$ by a mixed group of aggressors (parents + students). More than half of teachers $(58 \%)$ did not report it to the school management or the police, they are bullied and humiliated. Almost $2 / 3$ of them (64\%) responded that they think even if they reported to the police or leadership, nothing would happen.

In 2009-2012 the American Psychological Association carried several surveys of this kind on various samples of teachers. All were performed by the same/similar team or researchers from the universities in Illinois, Missouri, Kansas, Ohio, Texas etc. The results are very similar, though. 
When teachers reported the cyberbullying of their person to the headmaster, in $40 \%$ of cases the pupils, who attacked the teacher, were not punished. When teachers reported the situation to the police, in $77 \%$ of the cases nothing happened and the pupils were not punished (NASUWT, 2014).

Further research carried out by the American Psychological Association - Center for Psychology (CPSE) in collaboration with The National Education Association and the American Federation of Teachers in 2010 on the sample of 4,735 teachers from the USA (McMahon et al., 2011) confirmed that about half of American teachers $(50.9 \%, \mathrm{n}$ $=2,410$ ) became victims of harassment, verbal abuse, humiliation and even physical assault during the course of the year. The most common forms of aggression were obscene remarks, obscene gestures, verbal aggression and intimidation. Less frequent were attacks on the Internet, they were confirmed only by $2.6 \%$ of teachers (126 teachers).

Cyberbullying of teachers in the form of "cyberbaiting" (provoking the teacher in the classroom, recording his/her reaction and uploading the recording to the Internet) is also confirmed by a global research carried out by Norton Online Family Report (Daily Mail Reporter, 2011; Symantec, 2011) on a sample of 2,379 teachers from 24 countries - concluding that $21 \%$ of teachers became the victim of cyberbullying in the form of cyberbaiting. The research also highlights the dangers of online friendship $-34 \%$ of teachers in the environment social networking makes "friends" with their students so they voluntarily make themselves vulnerable to cyberbullying. $51 \%$ of teachers confirmed that their school has set rules determining how students and teachers should communicate in social networking sites (Chansanchai, 2011).

\subsection{Specifics of Cyberbullying of Teachers in the Czech Republic}

In the Czech Republic, elementary measurement of bullying and cyberbullying in the

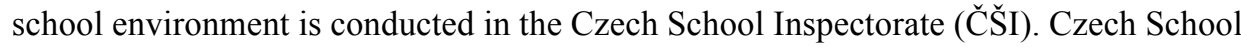
Inspectorate is a separate and independent administrative authority established by law, which ensures regular evaluation of the education system in the Czech Republic. The evaluation covers education and educational services provided by schools and educational institutions listed in the schools register.

According to the Czech School Inspectorate (Česká školní inspekce, 2015) 26.4\% of primary school teachers become victims of verbal aggression. $2.4 \%$ of primary school teachers also confirm that they have become victims of physical aggression against their person. In the environment of secondary schools verbal aggression was confirmed by $36.0 \%$ of schools (physical aggression in $4.7 \%$ ). It can be assumed however, that large quantities of such incidents are not reported to the Czech School Inspectorate.

In many cases school management attempts to cover up cyberbullying of teachers (and students too), not wanting to make the situation public needlessly, so as not to damage the school reputation and not to discourage parents from enlisting their children to the school. Therefore, the difference between the real situation and the official findings of the Czech School Inspection can be very large. This situation is also confirmed by the results of the national research of cyberbullying of teachers (see below). 


\section{Method}

The research of cyberbullying of Czech teachers was realized in the course of 2015 by the Centre of Prevention of Risky Virtual Communication at Palacký University in Olomouc in cooperation with the companies O2 Czech Republic and Seznam.cz.

\subsection{Procedure}

As the basic research tool was used an anonymous online questionnaire (in the environment of Google Forms), which was distributed to primary and secondary schools throughout the Czech Republic. Distribution of the questionnaire was conducted in collaboration with county and city managers and coordinators of risky behaviour prevention, who secured the distribution of questionnaires among teachers in different regions.

Preparation of research and testing of the validity and reliability of the research tool within the pilot survey took place from 1 January 2016 to 1 February 2016. Data collection took place from 14 February 2016 to 31 March 2016. In the following months the individual outputs were evaluated and interpreted. The data analysis used the statistical software Statistica.

\subsection{Research Participants}

The research involved a total of 5,136 respondents $\left(78.60 \%\right.$ female, $21.4 \%$ male $\left.^{2}\right)$ from all regions of the Czech Republic. The average age was 46.42 years $(\hat{x}=52.00, \tilde{x}=$ $4800)$, variance in the file reached the value of $\mathrm{s}^{2}=96.25048(\mathrm{~s}=9.810733)$.

The largest part of the group consisted of elementary school teachers $(60.22 \%)$ and secondary school teachers $(37.03 \%)$, and in the research also participated teachers from kindergartens, colleges and universities (together less than 3\%).

\subsection{Measurement}

For the purposes of our research there was created a research tool - an online questionnaire, which focused on acquisition of information about the prevalence of cyberbullying and cyber attacks on primary and secondary school teachers. The questionnaire was composed of 5 sections containing items focused on identifying demographic information about the respondents and the institutions, where they work, items focused on identifying the prevalence of cyber attacks against teachers, items intended to collect information about the perpetrators of the attacks, strategies that were employed in the attacks on teachers, and also information about how the cyberbullying of the teacher was solved. The research tool included a total of 44 items.

2 According to the official statistics of the Department of Education, Youth and Physical Training (Ministerstvo kolství, 2015) in the Czech Republic, the share of Czech male teachers in the first half of 2015 is $17.3 \%$. 


\subsection{Methodological Note}

In the research we use the method of interrogation in which we inquire about specific manifestations of cyberbullying, to which teachers were exposed. This approach allows examining a wide range of specific forms of cyber aggression and offers teachers the ability to highlight new forms of attacks. In order to simultaneously satisfy the commonly used definitions of cyberbullying (Li, 2007; Patchin and Hinduja, 2006; Willard, 2007a), we also measure the repetition rate of individual forms, their impact on the victims (on emotional, physiological and behavioural level) and the time interval during which the attacks on teachers lasted. To make the approach to the topic as comprehensive as possible, we also focus on strategies how to cope with cyberbullying that teachers adopted when solving the issue.

\section{Results}

\subsection{Prevalence of Cyberbullying in the Teacher Population}

In our research we focused on both the number of various forms of cyber attacks and their frequency, as well as their intensity and how long the attacks lasted. Respondents were first approached with the question whether they have been victims of any forms of cyber attacks (cyberbullying), while this attack must have been repeated, intense and had to have an impact on them (e.g. on emotional, behavioural level etc.). Respondents also reported whether the attack on their person occurred during the last 12 months, or earlier, and also how long the attack lasted, what was its intensity, who was the perpetrator and the like. These findings are analysed in more detail in other parts of this paper.

$21.73 \%(1,118$ of 5,136$)$ of the approached teachers became victims of some form of cyberbullying. $78.27 \%$ of teachers said that they were not victims of cyberbullying at all. The following table (Table 1) provides an overview of the most common manifestations of cyberbullying to which teachers are exposed.

In cyberspace, teachers most often become victims of verbal aggression, particularly humiliation, insults, embarrassment, gossip and ridicule. Other widespread forms of attacks include phone ringing, threats or intimidation or spreading of humiliating photos. Many cyber attacks (forms of cyberbullying) cannot be classified under the term cyberbullying, because it is necessary to determine whether the attacks were repeated, whether it was intense and whether it lasted for longer period of time. Therefore, in our research we also examined how long the attacks lasted, whether it was repeated, and whether it was so intense that the victim perceived it as wounding.

The results show that the predominant attacks are short, lasting less than 1 week. Long term attacks on teachers are rather exceptional, e.g. assaults longer than six months were confirmed only by $9 \%$ of all teachers, who have experienced an attack on their person (a total of 94 teachers out of 1,062).

We are aware that the data concerning the length of the attack provided by the teachers themselves may be limited - the attack on the teacher could have started before the 
Table 1

The most common forms of cyber attacks on teachers

\begin{tabular}{lll}
\hline Form & $\begin{array}{l}\text { Number } \\
\text { (n) }\end{array}$ & $\begin{array}{l}\text { Relative fre- } \\
\text { quency (\%) }\end{array}$ \\
\hline $\begin{array}{l}\text { Verbal attacks carried out with the use of a mobile phone and/or internet } \\
\text { (humiliation, insults, ridicule, embarrassment etc.). }\end{array}$ & 507 & 28.77 \\
Harassment by phone ringing (ongoing repeatedly, e.g. in the evening) & 457 & 25.94 \\
Threats or intimidation services via the Internet or mobile phone & 215 & 12.20 \\
Dissemination of degrading, humiliating or embarrassing photos & 162 & 9.19 \\
Penetration into the electronic account (email, account on a social network, etc.). & 141 & 8.00 \\
Dissemination of degrading, humiliating or embarrassing video $^{3}$ & 64 & 3.63 \\
Identity theft, misuse of electronic account $^{4}$ & 53 & 3.01 \\
Extortion via the Internet or mobile phone service $^{\text {Dissemination of degrading, humiliating or embarrassing sound recordings }}$ & 42 & 2.38 \\
Establishment of a false teacher's profile on a social network $^{2}$ & 39 & 2.21 \\
\hline
\end{tabular}

Table 2

Length of cyber attacks on teachers

\begin{tabular}{lcc}
\hline Length of attack & Number (n) & Relative frequency (\%) \\
\hline Less than 1 week & 456 & 42.94 \\
$1-2$ weeks & 227 & 21.37 \\
$3-5$ weeks & 117 & 11.02 \\
$1-3$ months & 115 & 10.83 \\
$4-6$ months & 53 & 4.99 \\
$7-12$ months & 27 & 2.54 \\
Over a year & 67 & 6.31 \\
\hline Total & $\mathbf{1 , 0 6 2}$ & $\mathbf{1 0 0}$ \\
\hline
\end{tabular}

Table 3

Cyberbullying of Czech teachers - Overview

\begin{tabular}{|c|c|c|c|c|}
\hline \multirow[t]{2}{*}{ Duration } & \multicolumn{2}{|c|}{ In the past 12 months } & \multicolumn{2}{|c|}{ More than 12 months ago } \\
\hline & Number (n) & Relative frequency (\%) & Number (n) & Relative frequency $(\%)$ \\
\hline Less than a week & 137 & 2.66 & 311 & 6.06 \\
\hline More than a week & 181 & 3.52 & 443 & 8.63 \\
\hline Total & 318 & 6.19 & 754 & 14.68 \\
\hline
\end{tabular}

3 It includes the situations where cyberbaiting occurred - a provoked situation which the pupils recorded on their mobile phone and then spread the recording.

4 It includes situations when the perpetrator broke into the teacher's account and used the account to cause trouble - e.g. molested friends of the teacher in cyberspace, sent vulgar or sexually explicit message under the name of the teacher etc. 
teacher and his colleagues learnt about it. Therefore, we can assume that the attacks on teachers lasted longer than specified in the summary Table 2.

Cyber attack against their person, occurring during the past 12 months, was confirmed 318 respondents, 754 respondents confirmed that they were victims of a cyber attack more than 12 months ago ${ }^{5}$. However, these data include also single incidents that were not repeated, the attack did not last a long time and was not intense, so we filtered the below, separated one-time incidents from repeated attacks on teachers, and separated data on incidents that occurred in the past 12 months and we also separated incidents in which teachers confirmed emotional, physiological (psychosomatic), or behavioural effect on their person. The resulting report provides the Table 3.

Cyberbullying, which took place in the past 12 months and lasted more than 1 week, was confirmed by a total of $\mathbf{3 . 5 2}$ teachers \% (181 of 5,136 respondents), cyberbullying generally longer than a week was experienced by $12.15 \%$ (624 of 5,136 respondents). Although $21.73 \%$ of teachers $(1,118$ of 5,136$)$ became the victims of cyber aggression, cyberbullying ongoing for more than a week was documented only in half of them $(55.81 \%)$.

In our research, we also focused on the question, what platforms are used for attacks on teachers. Most often the attacks use social networks (38.6\% of cases) and mobile phone services - usually SMS messages, anonymous phone calls or ringing (30.20\% of cases).

Due to the fact that the most frequently used tool of the attacks are social networks, we were interested to know, which of the social networks are used. The following table gives an overview of social networks (or social services) within which the attacks on teachers occur.

Cyber attack on their own person was confirmed by a total of 1,072 respondents $29.66 \%(n=318)$ of them confirmed that the attack on their person occurred during the past 12 months. $70.34 \%(n=754)$ of them said that the attack on their person occurred more than 12 months ago.

Attacks on teachers most often use the social networking site Facebook, which figures in more than $40 \%$ of attacks on teachers, which took place in the last 12 months. Other platforms that are used for attacks on teachers are the video sharing server YouTube (3.14\% of cases) and the Czech server for former classmates Spolužáci.cz (2.83\% of cases).

Czech servers aimed at evaluating of teachers (Hodnoceniucitelu.cz, Oznamkujucitele.cz, Primat.cz and others) are much less prominent in the statistics - many teachers do not consider a critical evaluation of the quality of their education work through such services as cyber bullying and cyber-attack on their person, but consider it as only critical expression of opinion. In the entire sample of teachers who have experienced a cyber attack against their person, only $1.30 \%$ of the respondents (14 of 1,072 teachers) confirmed that the attack was realized through these servers.

\footnotetext{
5 Some of the respondents did not stated how long the attack against their person lasted, though the length is
} important to define the cyberbullying. Therefore we did not include these respondents in further analyses. 
Table 4

Occurrence of traditional bullying in the examined group

\begin{tabular}{lccc}
\hline & Entire group (n) & $\begin{array}{l}\text { Have experienced } \\
\text { a cyber attack (n) }\end{array}$ & $\begin{array}{l}\text { Have not experienced } \\
\text { a cyber attack (n) }\end{array}$ \\
\hline Have experienced bullying & 321 & 148 & 173 \\
Have not experienced bullying & 4,814 & 968 & 3,846 \\
\hline Total & $\mathbf{5 , 1 3 5}$ & $\mathbf{1 , 1 1 6}$ & $\mathbf{4 , 0 1 9}$ \\
\hline
\end{tabular}

\section{Link between cyberbullying and traditional bullying}

In our research we also looked at whether teacher-aimed cyberbullying is connected with traditional forms of bullying, and whether teachers who experience cyberbullying have also been victims of traditional bullying (physical or psychological). Likewise, we examined how many teachers from our group experienced bullying (even in situations when bullying was not connected with cyberbullying) (Table 4).

A total of 321 teachers (Table 4) have become victims of traditional bullying, representing $6.25 \%$ of the examined group.

\subsection{Perpetrators of Cyberbullying}

In other parts of our research we focused on offenders who carry out single or complex attacks aimed at teachers. Firstly, we need to say that in $24.42 \%$ of cases $(n=272)$, the perpetrators of cyber attacks were not identified - and were not punished. In $68.02 \%$ cases the perpetrators were identified. In almost half of the cases (48.84\%) a single person was responsible, whereas in a fifth of cases the perpetrators attacked as a group (19.18\%). Now we shall focus on who the perpetrators are (Table 5).

Most often the perpetrators of cyber attacks on teachers are the pupils with whom the teacher is in regular contact - especially pupils whom the victim teaches $(34.92 \%)$. Although some research abroad (Posnick-Goodwin, 2012) indicates in almost a third of cases the offenders are parents, our research did not confirm that high participation of parents in cyberbullying of teachers. Our figures indicate that parents were involved in cyberbullying of teachers (or single-time attack on a teacher) only in $8.08 \%$ of cases.

In our research, we also focused on the people who knew that the teacher is experiencing cyberbullying (Table 6).

The victims believe that most often it was their own colleagues - teachers or tutors $(31.9 \%)$ - who knew about the cyberbullying (cyberattack). School management knew only in $15 \%$ of cases. The statements of teachers imply that school management (headmasters) is often not informed about cyberbullying of their staff. In many cases the victim does not actually know which people knew about the cyberbullying of their person. 
Table 5

Perpetrators of Cyberbullying of Teachers

\begin{tabular}{|c|c|c|c|}
\hline Perpetrator & Details & $\begin{array}{l}\text { Number } \\
\text { (n) }\end{array}$ & $\begin{array}{l}\text { Relative } \\
\text { frequency (\%) }\end{array}$ \\
\hline \multirow[t]{4}{*}{ Pupil or group of pupils } & $\begin{array}{l}\text { Pupil or a group of pupils, known by the victim. } \\
\text { The victim teaches them. }\end{array}$ & 389 & 34.92 \\
\hline & $\begin{array}{l}\text { Pupil or group of pupils, known by the victim. } \\
\text { The victim does not teach them. }\end{array}$ & 35 & 3.14 \\
\hline & $\begin{array}{l}\text { Pupil or group of pupils from the school where } \\
\text { the victim teaches but does not know them in } \\
\text { person. }\end{array}$ & 20 & 1.80 \\
\hline & $\begin{array}{l}\text { Pupil or group of pupils from another school. Not } \\
\text { the school where the victim teaches. }\end{array}$ & 5 & 0.45 \\
\hline Parents of the pupil & Parents of the pupil & 90 & 8.08 \\
\hline \multirow[t]{2}{*}{ Colleague of the victim } & Colleague - not his/her superior & 30 & 2.69 \\
\hline & Colleague - his/her superior (e.g. headmaster) & 10 & 0.90 \\
\hline \multirow[t]{2}{*}{ Combination } & Pupils and their parents & 24 & 2.15 \\
\hline & Colleagues from work and parents & 7 & 0.63 \\
\hline Perpetrators not identified & & 272 & 24.42 \\
\hline Other people & $\begin{array}{l}\text { Individuals who are not at the school, for example } \\
\text { an ex-partner, neighbour, acquaintance etc. }\end{array}$ & 137 & 12.30 \\
\hline N/A & & 95 & 8.52 \\
\hline Total & & 1,114 & \\
\hline
\end{tabular}

Table 6

Persons who knew about cyberbullying of the teacher

\begin{tabular}{lcc}
\hline Persons & Number (n) & Relative frequency (\%) \\
\hline Colleagues - teachers, tutors & 356 & 31.90 \\
School headmaster & 168 & 15.05 \\
No one except the aggressor knew about the cyberbullying & 142 & 12.72 \\
Pupils & 79 & 7.08 \\
Victim's family & 37 & 3.32 \\
Parents of pupils & 15 & 1.34 \\
Police & 4 & 0.36 \\
\hline Total & $\mathbf{1 , 1 1 6}$ & \\
\hline
\end{tabular}

\subsection{Basic Strategy for Coping with Cyberbullying}

Teachers who are victims of one-time cyber attacks or victims of cyberbullying use a large variety of methods and procedures aimed mainly at removing the consequences of an attack. 
Table 7

Overview of the most common strategies for coping with cyberbullying

\begin{tabular}{|c|c|c|c|c|c|c|c|}
\hline & \multicolumn{3}{|c|}{ Entire group } & \multicolumn{2}{|c|}{$\begin{array}{l}\text { Incidents } \\
\text { lasting less } \\
\text { than } 1 \text { week }\end{array}$} & \multicolumn{2}{|c|}{$\begin{array}{l}\text { Incidents } \\
\text { lasting more } \\
\text { than } 1 \text { week }\end{array}$} \\
\hline & 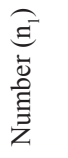 & 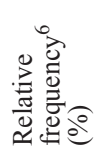 & 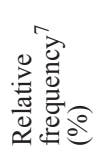 & 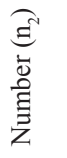 & 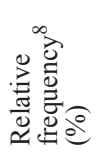 & 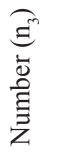 & 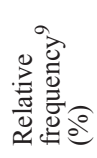 \\
\hline \multicolumn{8}{|l|}{ Technical solutions } \\
\hline $\begin{array}{l}\text { Erasing objectionable content (e.g. photos, } \\
\text { videos, inappropriate profile etc.). }\end{array}$ & 250 & 12.38 & 22.40 & 112 & 13.38 & 138 & 11.69 \\
\hline $\begin{array}{l}\text { Blocking objectionable content (content is not } \\
\text { deleted, but not visible) }\end{array}$ & 76 & 3.76 & 6.81 & 30 & 3.58 & 46 & 3.90 \\
\hline Blocking the profile of the offender & 92 & 4.56 & 8.24 & 34 & 4.06 & 58 & 4.91 \\
\hline $\begin{array}{l}\text { Blocking access to specific Internet services } \\
\text { in the school system (e.g. blocking access to } \\
\text { Facebook, Ask.fm etc.). }\end{array}$ & 28 & 1.39 & 2.51 & 10 & 1.19 & 18 & 1.52 \\
\hline Archiving of all evidence (of communication) & 195 & 9.66 & 17.47 & 76 & 9.08 & 119 & 10.08 \\
\hline $\begin{array}{l}\text { Determining the identity of the perpetrator } \\
\text { (e.g. through other pupils, research of profiles } \\
\text { on social networks, analysis of e-mail headers, } \\
\text { etc.). }\end{array}$ & 162 & 8.02 & 14.52 & 68 & 8.12 & 94 & 7.96 \\
\hline Reading the e-mail of the suspect pupil & 11 & 0.54 & 0.99 & 9 & 1.08 & 2 & 0.17 \\
\hline Blocking a phone number in one's own mobile & 4 & 0.20 & 0.36 & 0 & 0.00 & 4 & 0.34 \\
\hline Changing one's own phone number & 2 & 0.10 & 0.09 & 0 & 0.00 & 1 & 0.08 \\
\hline Change of e-mail & 2 & 0.10 & 0.18 & 1 & 0.13 & 1 & 0.08 \\
\hline Changing the password & 6 & 0.30 & 0.54 & 5 & 0.60 & 1 & 0.08 \\
\hline \multicolumn{8}{|l|}{ Addressing the situation in school environment } \\
\hline $\begin{array}{l}\text { Questioning of students (informants, onlo- } \\
\text { okers) }\end{array}$ & 148 & 7.33 & 13.26 & 67 & 8.00 & 81 & 6.86 \\
\hline $\begin{array}{l}\text { Discussion with the class (interview with the } \\
\text { whole class, role playing ...) }\end{array}$ & 86 & 4.26 & 7.71 & 38 & 4.54 & 48 & 4.06 \\
\hline Seizure of a pupil's mobile phone & 12 & 0.59 & 1.08 & 6 & 0.72 & 6 & 0.51 \\
\hline Seizure of a pupil's tablet & 1 & 0.05 & 0.09 & 1 & 0.12 & 0 & 0.00 \\
\hline $\begin{array}{l}\text { Reporting the situation to the headmaster and } \\
\text { asking for remedy }\end{array}$ & 101 & 5.00 & 9.05 & 41 & 4.90 & 60 & 5.08 \\
\hline Appeal to the aggressor to remove the content & 81 & 4.01 & 7.26 & 34 & 4.06 & 47 & 3.98 \\
\hline Interview with the parents of the offender & 132 & 6.54 & 11.83 & 65 & 7.77 & 67 & 5.67 \\
\hline \multicolumn{8}{|c|}{ Resolving the situation with the aid of external persons / entities } \\
\hline I used the help of specialists (e.g. IT) & 66 & 3.27 & 5.91 & 22 & 2.63 & 44 & 3.73 \\
\hline $\begin{array}{l}\text { Consultation with the founder/owner of the } \\
\text { school }\end{array}$ & 25 & 1.24 & 2.24 & 8 & 0.96 & 17 & 1.44 \\
\hline
\end{tabular}

6 Calculated relative frequency in relation to the sum of all recorded incidents $(n=2019)$.

7 Calculated relative frequency in relation to the sum of all cyberattack victims $(n=1116)$.

8 Calculated relative frequency in relation to the number of all victims of cyberattacks lasting less than one week $(n=837)$.

9 Calculated relative frequency in relation to the number of all victims of cyberattack (cyberbullying) lasting more than 1 week $(n=1181)$. 


\begin{tabular}{|c|c|c|c|c|c|c|c|}
\hline $\begin{array}{l}\text { Consultation with OSPOD (Authority Child } \\
\text { protection) }\end{array}$ & 15 & 0.74 & 1.34 & 7 & 0.84 & 8 & 0.68 \\
\hline $\begin{array}{l}\text { Consultation with the staff of the Police of the } \\
\text { Czech Republic }\end{array}$ & 82 & 4.06 & 7.35 & 26 & 3.11 & 56 & 4.74 \\
\hline \multicolumn{8}{|l|}{ Ignoring the situation } \\
\hline $\begin{array}{l}\text { Ignoring the situation (we do not consider it } \\
\text { serious, so we do not take any steps) }\end{array}$ & 167 & 8.27 & 14.96 & 62 & 7.41 & 105 & 8.89 \\
\hline \multicolumn{8}{|l|}{ Other options } \\
\hline $\begin{array}{l}\text { Revenge of the aggressor (using electronic } \\
\text { means) }\end{array}$ & 4 & 0.20 & 0.36 & 2 & 0.24 & 2 & 0.17 \\
\hline $\begin{array}{l}\text { Revenge of the aggressor (without the use of } \\
\text { electronic means - e.g. in class) }\end{array}$ & 3 & 0.15 & 0.27 & 2 & 0.27 & 1 & 0.08 \\
\hline Total & 1,116 & & & 456 & & 660 & \\
\hline
\end{tabular}

Note: Teachers combine the individual strategies, for example content blocking, archiving materials, identifying the offender and his punishment.

The research results show that most teachers use strategies aimed directly at removing or blocking objectionable content from Internet - they make up more than a fifth $(22 \%)$ of all strategies used in defence. Nearly 10 percent of respondents $(9.66 \%)$ also makes records of the incidents - e.g. snapshots of the communications, SMS records etc. $8 \%$ of teachers also tried to track down the perpetrators of the attack. $8.25 \%$ of teachers chose to ignore the situation - either it did not consider it serious, or assumed that the problem will go away anyway.

\section{Discussion}

Comparing the results of our research with the results of research carried out since 2007 in Europe and the USA, we arrive at approximately the same findings - about a fifth of Czech teachers (21.73\%) experience various cyber forms of attacks, however in most cases they are one-time attacks and do not leave permanent consequences on the teachers.

There could be more reasons, why the prevalence of cyber-attacks in on the similar level in USA and EU countries:

1. The rapid expansion of information and communication technology among students (smartphones, tablets, notebooks) who misuse IT to attacks on teachers and also on another students (Tomczyk and Kopecký, 2015).

2. The growing number of young users of social networks (Facebook, G+) who can spread humiliating materials among huge online crowd.

3. Disturbed relationships between teachers, school management, parents and students, which may lead to personal attacks in real life and also in online environment. This issue was described in UK, USA, Germany, Finland, Czech Republic, Slovak, Poland and other EU countries (Association of Teachers and Lecturers, 2009; European Union, 2013; Garrett, 2014; GEW, 2008; Kopecký and Szotkowski, 2016; Kyriacou and Zuin, 2015; Tomczyk and Kopecký, 2015). 
4. Low prestige of the teaching profession in post-communist countries (especially in Visegrad Group Countries), modest salaries, stress, risks of burnout (European Union, 2013).

5. Aging of teachers (for example average age of teacher is 45 years) - young teachers are looking for another more profitably (less stressful) employment.

In the Czech environment, serious forms of cyberbullying are experienced only by a fraction of them - about $6 \%$ of Czech teachers in the last 12 months. These data correspond to the results of German studies (GEW, 2008), according to which cyberbullying is experienced by $8 \%$ of teachers, similar results are confirmed by Finnish researchers (Kauppi and Pörhölä, 2012a, 2012b), who measured the prevalence of cyberbullying at $7.6 \%$ of teachers who became victims of bullying. US study carried out by the Task Force on Violence Directed Against Teachers (Espelage et al., 2013; McMahon et al., $2011,2014)$ then states that ca $2.6-4 \%$ of teachers became victims of an attack on the Internet environment.

Although some studies have reported a high number of cyberbullied teachers - e.g. research carried out in the USA reported incidence of cyberbullying ranging $26 \%$ to $35 \%$ (Pearson, 2014; Posnick-Goodwin, 2012) - these studies usually include even one-time cyberattacks, which did not have (did not need to have) serious impact on the victim. It is also very important to separate whether the teacher has experienced cyberbullying in a limited period of time - usually in the course of the last 12 months. If we question teachers whether they have "ever in their life" experienced cyberbullying, we will certainly obtain high prevalence values that that do not reflect the current situation.

All the examined surveys of bullying or cyberbullying of teachers confirm that the most frequent perpetrators of cyber attacks are pupils or students, supported by parents to a lesser extent. This situation is confirmed by our research (in almost $40 \%$ of attacks on teachers the perpetrator was a pupil) and the Plymouth University research (PosnickGoodwin, 2012), which states that pupils accounted for $72 \%$ of attackers.

According to the respondents themselves - a large number of victims do not report to anyone that they experienced bullying or cyberbullying. The most common cause is explained further in the text.

\section{Why do teachers not report cyberbullying?}

It is very difficult to determine how much cyberbullying of teachers is widespread in population because teachers often do not report the attack against their person (NASUWT, 2014) - neither to the school management nor other institutions (e.g. the school founder). Teachers often do not want to draw unnecessary attention to the aggression to which they are exposed - because they perceive it as their own failure as something they provoked and what they bear the consequences (Iqbal, 2012; Kopecký, 2016). Ignoring or downplaying the problem is a common defence strategy, which is the least efficient and does not solve the problem in any way.

Many teachers also believe that the problem will go away and disappear anyway (Kopecký and Szotkowski, 2016; Steeves, 2014) - they do not realize, however, that their passivity provides a poor role model to all pupils who know about any bullying or cyberbullying - as if they were signalling to the pupils "you can harm other people and 
you will get away with it". Among other reasons why teachers do not report bullying or cyberbullying to their superiors, is the belief that the school management won't do anything, won't solve the situation, won't punish the perpetrators anyway (Iqbal, 2012; NASUWT, 2014). So from the perspective of the teacher it is therefore useless to report the problem because it will only draw unwanted attention to himself/herself but the remedy won't be achieved. Another reason why teachers do not report bullying or cyberbullying is uncertainty as to whether the school management will support the teacher (victim) and stand at his/her side (Iqbal, 2012; McMahon et al., 2014).

In the Czech Republic there are documented dozens of cases in which the school management did not support the opinion of the teacher, stood on the side of the parents of the aggressors against the views of teachers and suspended the process of punishing the pupil (Kopecký, 2016).

A very common reason is also the unwanted publicity (Franks, 2010) that the school might be exposed to if the case of a bullied teacher was published in media. Teachers and school management cover-up cyberbullying because they want to ensure that information about the existence of bullying or cyberbullying in the school is not published. Because it could negatively affect the number of enrolled students - as parents might not want to send their children to such school where bullying and cyberbullying occurs.

In this context, school management is also often afraid of possible inspection (Kopecký and Szotkowski, 2016) that might uncover some shortcomings in the enforcement of internal norms, insufficiently carried out Minimum Prevention Programme in the school etc.

\section{Conclusions}

The research results showed that although teachers do experience single or repeated attacks by pupils, only a small portion of them experience serious forms of cyber aggression. Most cases are one-off incidents, which are quickly addressed and stopped.

Cyber attack on his/her person was experienced in the last 12 months by $6.19 \%$ of the respondents. However only a half of them (55.81\%) experienced cyberbullying in the last 12 months and lasting more than one week - that is $3.52 \%$ of the respondents (181 of 5,136$)$. Traditional bullying was experienced by $6.25 \%$ of the respondents $(321$ of 5,135$)$.

The most frequent perpetrators of cyberbullying are pupils (in $40 \%$ of cases) and parents $(8.08 \%)$. In a fifth of cases $(24.42 \%)$ the identity of the perpetrator was not determined at all. In a number of cases $(12.30 \%)$ the perpetrator of cyberbullying was someone who is not associated with the school environment - e.g. ex-partner, neighbours, an acquaintance etc. The people who know about cyberbullying of the victim are usually the colleagues ( $31.9 \%$ of cases) and headmaster ( $15.05 \%$ of cases).

The most common strategies for dealing with cyberbullying include in particular blocking or deletion of harmful content on the Internet, archiving evidence or attempt to determine the identity of the perpetrator. In $8.27 \%$ the teachers ignore the situation they do not consider it as serious and believe that the problem will go away. 


\section{References}

Association of Teachers and Lecturers. (2009). Violent Pupils and Parents Make Teachers Lives a Misery. London.

Česká školní inspekce. (2015). Výročni Zpráva za Školni Rok 2014/2015 [Annual Report of Czech School Inspection]. Praha. Retrieved from

http://www.csicr.cz/html/VZ2014-15v2/flipviewerxpress.html

Daily Mail Reporter. (2011, November). Pupils 'abusing teachers and posting videos of their reaction online when they snap'. MailOnline. Retrieved from

http://www.dailymail.co.uk/sciencetech/article-2062367/One-teachers-taunted-cyberbaiting-pupils-know-colleague-been.html

Espelage, D., Anderman, E.M., Brown, V.E., Jones, A., Lane, K.L., McMahon, S.D., ... Reynolds, C.R. (2013). Understanding and preventing violence directed against teachers: recommendations for a national research, practice, and policy agenda. The American Psychologist, 68(2), 75-87.

http://doi.org/10.1037/a0031307

Espelage, D., Anderman, E.M., Brown, V., Jones, A., Lane, K.L.L., McMahon, S.D., ... Reynolds, C. (2011). Understanding and Preventing Violence Directed Against Teachers. Recommendations for a National Research, Practice and Policy Agenda.

European Union. (2013). The Attractiveness of the Teaching Profession in Europe (Vol. 1). http://doi .org/10.2766/40827

Franks, L. (2010, January). How to Stop a Bully. The Daily Beast. Retrieved from http://www. thedailybeast.com/articles/2010/03/31/how-to-stop-a-bully.html

Garrett, L. (2014). The Student Bullying of Teachers : An Exploration of the Nature of the Phenomenon and the Ways in which it is Experienced by Teachers . Aigne, (5), 19-40.

GEW. (2008, February 22). GEW stellt Studie zu Cybermobbing vor. Retrieved 22 February 2016, from http://www.gew.de/aktuelles/detailseite/neuigkeiten/gew-stellt-studie-zu-cybermobbing-vor/

Hinduja, S., Patchin, J.W. (2009). Bullying Beyond the Schoolyard: Preventing and Responding to Cyberbullying. Retrieved from

https://books.google.cz/books/about/Bullying_Beyond_the_Schoolyard.html?id $=$ SU5RT Jc0k68C\&pgis $=1$

Hollá, K. (2012). Kyber ikanovanie učitel'ov [Cyberbullying targeted on teachers]. Pedagogika.sk, 3(3), 166180 .

Chansanchai, A. (2011, November). Report: More kids 'cyberbaiting' teachers. Today Money. Retrieved from http://www .today.com/money/report-more-kids-cyberbaiting-teachers-119015

Iqbal, N. (2012, May 8). 'Cyberbullying on social media forced me out of teaching'. $B B C$. Retrieved from http://www.bbc.co.uk/newsbeat/article/17956218/cyberbullying-on-social-mediaforced-me-out-of-teaching

Kauppi, T., Pörhölä, M. (2012a). School teachers bullied by their students: Teachers' attributions and how they share their experiences. Teaching and Teacher Education, 28(7), 1059-1068.

http://doi.org/10.1016/j.tate.2012.05.009

Kauppi, T., Pörhölä, M. (2012b). Teachers Bullied by Students: Forms of Bullying and Perpetrator Characteristics. Violence and Victims, 27(3), 396-413.

http://doi.org/10.1891/0886-6708.27.3.396

Kopecký, K. (2016). Úvod do problematiky kyberšikany páchané na učitelích [Introduction to problem of cyberbullying aimed on teachers]. Retrieved 23 February 2016, from

http://www.e-bezpeci.cz/index.php/temata/kyberikana/1120-kybersikana-ucitelu-vyzkum

Kopecký, K., Szotkowski, R. (2016). Cyberbullying, cyber aggression and their impact on the victim - the teacher. Telematics and Informatics, 34(2), 506-517.

http://doi.org/10.1016/j.tele.2016.08.014 
Kyriacou, C., Zuin, A. (2015). Cyberbullying of teachers by students on YouTube: challenging the image of teacher authority in the digital age. Research Papers in Education, 1522(October), 1-19. http://doi.org/10.1080/02671522.2015.1037337

Li, Q. (2007). New bottle but old wine: A research of cyberbullying in schools. Computers in Human Behavior, 23(4), 1777-1791. http://doi.org/10.1016/j.chb.2005.10.005

Lipsett, A. (2009). Cyberbullying 'affects 1 in 10 teachers'. The Guardian. Retrieved from http://www. theguardian.com/education/2009/apr/04/cyber-bullying-schools-teachers-survey

McMahon, S.D., Espelage, D., Anderman, E.M., Lane, K.L., Reynolds, C., Brown, V., Jones, A. (2011). National Survey of Violence Against Teachers APA.

McMahon, S.D., Martinez, A., Espelage, D., Rose, C., Reddy, L.A., Lane, K., ... Brown, V. (2014). Violence directed against teachers: results from a national survey. Psychology in the Schools, 51(7), 753-766. http://doi.org/10.1002/pits

Ministerstvo kolství, mládeže a tělovýchovy. (2015). Genderová problematika zaměstnanců ve školství [Gender problems of school employees]. Retrieved 5 April 2016, from

http://www.msmt.cz/vzdelavani/skolstvi-v-cr/statistika-skolstvi/genderova-problematika-zamestnancu-ve-skolstvi

NASUWT. (2014). Abuse of Social Media Rife in Schools. Retrieved 21 February 2016, from http://www . nasuwt .org. uk/What snew/NASUWTNews/PressReleases/AbuseOfSocialMediaRifeInSchools

Patchin, J.W., Hinduja, S. (2006). Bullies Move Beyond the Schoolyard: A Preliminary Look at Cyberbullying. Youth Violence and Juvenile Justice, 4(2), 148-169. http://doi.org/10.1177/1541204006286288

Pearson, J. (2014). Kids Are Cyberbullying Their Teachers. Motherboard. Retrieved from http://motherboard.vice.com/read/kids-are-cyberbullying-their-teachers

Posnick-Goodwin, S. (2012). Cyberbullying of Teachers. Retrieved 23 February 2016, from http://www.cta.org/en/Professional-Development/Publications/2012/03/March-Educator-2012/Cyberbullying-of-teachers.aspx

Reddy, L. a., Espelage, D., McMahon, S.D., Anderman, E.M., Lane, K.L., Brown, V.E., ... Kanrich, J. (2013). Violence Against Teachers: Case Studies from the APA Task Force. International Journal of School \& Educational Psychology, 1(4), 231-245.

http://doi.org/10.1080/21683603.2013.837019

Slonje, R., Smith, P.K., Frisén, A. (2013). The nature of cyberbullying, and strategies for prevention. Computers in Human Behavior, 29(1), 26-32. http://doi.org/10.1016/j.chb.2012.05.024

Steeves, V. (2014). Young Canadians in a Wired World, Phase III: Cyberbullying: Dealing with Online Meanness. Retrieved from http://mediasmarts.ca/ycww

Symantec. (2011). Norton Cybercrime Report 2011. Retrieved 21 February 2016, from http://now-static.norton.com/now/en/pu/images/Promotions/2012/cybercrime/assets/ downloads/en-us/NCR-DataSheet.pdf

Tomczyk, Ł., Kopecký, K. (2015). Children and Youth Safety on the Internet: Experiences from Czech Republic and Poland. Telematics and Informatics, 33(3). http://doi.org/10.1016/j.tele.2015.12.003

Willard, N. (2007a). Cyberbullying and Cyberthreats: Responding to the Challenge of Online Social Aggression, Threats, and Distress (1st ed.). Champaign, IL: Research Press.

Willard, N. (2007b). Educator 's Guide to Cyberbullying and Cyberthreats (1st ed.). Center for Safe and Responsible Use of the Internet. 
K. Kopecký, PhD, assistant professor at Palacký University, head of Centre for the prevention of risky virtual communication Faculty of Education of Palacký University in Olomouc a head of Project E-Bezpeci. Dr. Kopecký focuses on prevention of hazardous behaviour associated with the use of information and communication technologies by children, especially cyber bullying, cyber grooming, cyber stalking, hoax and spam, sexting, social engineering methods, the issue of sharing of personal information through social networks and other dangerous communication techniques. He also focuses on positive using of modern IT technologies by children and adults.

R. Szotkowski, PhD, assistant professor at Palacký University, head of science at Centre for the prevention of risky virtual communication Faculty of Education of Palacký University in Olomouc and a lecteur of Project E-Bezpeci. Dr. Szotkowski focuses on prevention of hazardous behaviour associated with the use of information and communication technologies by children, especially cyber bullying, cyber grooming, cyber stalking, hoax and spam, sexting, social engineering methods, the issue of sharing of personal information through social networks and other dangerous communication techniques. He also focuses on positive using of modern IT technologies by children and adults. 